\title{
Demand for heterosexual commercial sex services in Ibadan, Nigeria
}

\author{
Olanrewaju Olaniyan ${ }^{1}$, Noah Olasehinde ${ }^{1}$, Adewuyi Akintaro ${ }^{2}$ \& Olabisi Afolabi ${ }^{1}$ \\ ${ }^{1}$ Health Policy Training and Research Programme, \\ Department of Economics, University of Ibadan, Nigeria \\ ${ }^{2}$ Department of Economics, Crescent University, Abeokuta, Nigeria \\ lanfaithfulness@hotmail.com
}

\begin{abstract}
Context/Backgroud: This paper examines the demand for heterosexual commercial sex services in Ibadan, Nigeria with specific focus on the sub-markets where different commercial sex activities are usually traded. Identified players include commercial sex workers (females), clients (males) and intermediaries (exploiters).

Data Sources \& Method: This study employed multi-stage sampling procedure. At the first stage, the most populous local government area in Ibadan was purposively selected; for the second stage, ten locations where commercial sex work exists were purposively selected while eighteen (I8) clients were randomly and discretely selected from each of the sites at the last stage. The eventual sample size was one hundred and sixty-eight (168) clients. The empirical model derived from the rational addiction theory and it was estimated using Ordinary Least Squares (OLS) technique.

Results: The results show that the demand is highly responsive to age, marital status, income, tastes and preferences and the price (with respect to condom usage). Clubs/bars, streets and houses were the highly patronised sub-markets, though the demand was increasing with short time and per night services in some sub-markets, it was decreasing in others. The nature of risk became more pronounced with clubs/bar clients being more risk loving while others were risk averse in other sub-markets based on their respective significant condom usage.
\end{abstract}

Keywords: demand, heterosexual, Nigeria, commercial sex services, sub-markets

\section{Introduction}

Economic incentives are bound to attract people to any income generating activity and the demand for a commodity implies willingness and ability to exchange the given commodity at a given price level. The legality or otherwise of such commodities depends on the promulgation and enforcement of the extant law guiding their productions.' Though, the economic or other implications of the consumption of illegal goods compel government to discourage their production and consumption, no matter how stringent the laws against them are, for one reason or the other, citizens still find ways around production and consumption of such goods (Della Giusta et al 2008).

The paradox of the existence of illegal commodities is that it spurred the unusual rise in social vices globally; this growth is alarming and multidimensional with commercial sex service becoming prominent among those threatening the continuous human survivali (Raymond, 2004; Farley, 2003; Cockayne, 200I). Commercial sex service is seen as a multi-million trans-national industry that mobilises millions of workers, regulated in widely different ways and highly fragmented in different markets, in 3737 which different types of intermediaries are present (Della Giusta et al 2008). Commercial sex service refers to the sale of sexual services to achieve a certain goal different from procreation or pleasure (Ogunkan et al, 2010). It simply means the act of engaging in sexual activities willingly with individuals other than a spouse or friend for immediate payment in money or other valuables. A commercial sex worker, is a man or woman of consenting age who exchange sexual services for payment in either heterosexual or homosexual activity. The commercial sex workers supply the sexual activities, while the clients on the other hand demand for those services and historically most commercial sex workers have been females while males served as clients. Although, females' demand for commercial sex services has been argued by Aggleton (1998) and Taylor (200I), overwhelming evidence abound affirming that the majority of demand is from males (Posner, 1992; Philipson and Posner, 1993; Mansson, 2005).

Three basic facts that emerge from Alobo and Ndifon (2014) on commercial sex work are that firstly; it is sexual in nature, and the reward could be money or other material goods that are exchanged at http://aps.journals.ac.za 
or near the time of the act. Secondly, the relationship between the provider and the recipient of sexual services did not involve love or affection and finally, it is a career practised on either full-time or part-time basis by individuals of different races and ages for both the opposite and the same sex. Furthermore, commercial sex workers are not necessarily females or adult; male and female commercial sex workers of various ages provide sexual services.

The commercial sex work industry is made up of the clients, commercial sex workers and intermediaries (exploiters include traffickers, pimps, brothel owners, "aristos" - slang in most universities meaning an elderly and rich patroniser of usually very young commercial sex workers; organized crime members and corrupt officials) who make money from the sale of sex as a commodity (Cockayne, 200I). The services encompass all forms of engagement in sex industry which include vaginal intercourse, anal and oral sex, fellatio, fondling and caressing, lap dancing, pornographic acting, etc. Commercial sex service exists as a balance between the supply of available commercial sex workers and the demand for commercial sex worker to provide the sexual acts which begins when clients go in search of sex that can be purchased. Within the African context, sex suppliers are often from marginalized, poor, and vulnerable populations. These naïve and easy to control men or women, oftentimes might have been sexually abused until their bodily integrity and identities are destroyed and they no longer know how to resist abuse and exploitation (Hughes 2004).

The common prejudices in the literature with both buying and selling of commercial sex service centre on moral degradation and economic desperation. Though, it is a necessary income generating activity that is influenced by the seemingly lack of alternative earning opportunities, nonreproductive extramarital sex has been viewed as immoral which is the attached social stigma (Nussbaum 1999). Aside, the market is riddled with the potential for reputational losses, which reduced from actual to a lower level than the original reputation potential (West 1992). These reputational losses can manifest in the inherent feelings of shame and guilt that result from spouse's reaction, marital instability, etc. So also is the attendant health risk.

Though, the concept of commercial sex service has been largely ignored in academic debate in spite of its recent visibility and immensity both locally and internationally (Marttila 2003), the economic literature on commercial sex service is vast and conducted up to the recent period (Ryley, 1936; Fels, 197I; Reynolds, 1986; Cameron et al, 1999; Edlund and Korn, 2002; Gertler et al. 2005; Adriaenssens, 2010 and Cook et al, 20I4). The high growth of sex industry in Africa recently is highly connected with rapid and wide ranging socio-economic changes and globalization which has affected the value structure of African society (Alobo and Ndifon 2014). This expansion has been linked to the fact that the commercial sex work industry is a market that is poorly regulated, widely stigmatized, and partly criminalized in many African nations.

In most African settings, religious and cultural precepts guiding sexual activities are clear, unambiguous and are expected to be complied with. These limit the goal of the activities to procreation or pleasure; therefore, it precludes the possibility of monetary gain. Specifically in Nigeria, commercial sex work is currently an illegal trade and this criminalises activities in its market. The illegality is due to its prohibition by law as found in Sections $222 \mathrm{~A}$ and 222B of the Nigerian Criminal Code. This, notwithstanding, the market not only continue to exist, its transactions seem thriving.

In the like manner, commercial sex studies have also received attention in Nigeria. Ausbeth-Ajagun (2005) identified factors influencing commercial sex work in the country to include poverty, laziness, greed and avarice, broken home, poor parental upbringing, deceptive media appeal, harsh economic condition, abandonment by family members, godlessness, inadequate job opportunities, distorted value system and ignorance. However, the health implications that have been linked with the commercial sex market include sleep disorder, mood disorder, general somatic disorder (Akinnawo 1995) and exposure to sexually transmitted diseases (STDs) (Asowa-Omorodion 2000). All these factors were supported and reinforced by Adesina (2006), Ogunkan et al (20I0), Babatola (20I I) and Alobo and Ndifon (20I4). It is noteworthy that the studies mainly focus on supply side of the market with little or no evidence on the demand side, which has proved, overtime, to be the driving force in the commercial sex market. Therefore, this study intends to investigate the seemingly neglected demand side of the market emphasising the factors driving the supposed illegal but thriving sex market in Ibadan, Oyo State Nigeria.

Few thoughts that serve as rationale for this paper include the fact that the commercial sex market in Nigeria is dominated by female sellers who outnumber male sellers; more so, it has been established that male heterosexual commercial sex work is scarce because of low earnings due to the fact that women rarely pay men for commercial sex (Cameron, et al 1999). Also, polyandry (simultaneous marriage of several men to one woman) does not have cultural basis in Nigeria. Furthermore, homosexual relationship is illegal and its 
commercialisation is highly hidden wherever it is being practised owing to its cultural abhorrent. The next section presents the literature review and theoretical framework followed by thedata and method in section 3. Section 4 contains results and discussion section 5 presents the conclusion and some policy implications.

\section{Literature review and theoretical framework}

The debate on the factors that determine the demand for female heterosexual commercial sex services has centred on the existence of a (formal or informal) marital relationship of buyers (Hubbard, 1998). These factors have been argued to include a wide range of psychological, genetic, economic, social and geographical factors (Cameron and Collins 2003). The existing relationship provides adequate companionship and emotional support while a commercial sex worker treat sex as work and thereby maintains emotional detachment from clients.

For men without existing relationships, it raise the relative search costs of finding willing sexual partners (or partners willing to engage in specific sexual activities) in an ad hoc or formal social context, and in a given time period (Cameron and Collins 2003). The psychological and genetic factors include dislike of emotional entanglements, low self-esteem in conventional social gatherings and perceptions about one's level of physical attractiveness (height, facial look, etc). Other factors are unsocial working hours, persistent gender imbalances at work, thin markets for potential sexual partners in some rural areas and pervasive social controls (community disapproval) in some religious communities against pre-marital sexual activity. However, for those in existing relationships, the demand is likely to be motivated by a need to satisfy a higher frequency of sexual urge than one's relationship partner is willing to take, need for variety or to engage in specific sexual activities, which the existing relationship partner is not prepared to accommodate; sexual refuge motive (sexual outlet during bouts of marital conflict), or an outlet for relieve from other forms of stress and tension (Albert, Gomez and Franco 2007).

The commercial sex industry has been organized according to similar principles across different times and cultures (Edlund and Korn, 2002) and given different working conditions; the earnings from its voluntary transactions make it an economic activity. Nonetheless, most clients do not communicate openly about their practices, and actively conceal it, oftentimes; for fear of damaged reputations which ensure that most commercial sexual services take place in the informal or underground location (Levitt and Venkatesh 2007). Typically, price and quality differentials, scales of operation, role of intermediaries (individual or corporate), communication channels, the existing contractual defence and presence of externalities characterises the commercial sex market in the literature.

The candidate factors that have notably influenced the demand for commercial sex service in the literature include the price which refers to the amount paid for the service, service quality which involves the experience, age and health of the commercial sex worker, location as well as the time, nature and duration of the transaction (Moffatt and Peters, 2004; Babalola, 20II). Another factor is the scale of operation, that is, whether it is on full-time or part-time basis; duration-based services are short time, till-day-break, weekend, VIP escort and so on. Based on these factors, Albert et al (2007) summarised the attendant externalities of the commercial sex market to include:

i. Health effects, which is basically the spread of sexually transmitted diseases (STDs);

ii. Public disorder, which involves public scandal or outrage relating to the exhibition of commercial sex workers marketing their services in specific locations; crimes often associated to commercial sex work - assault, robbery, rape, and other expressions of abuse and violence;

iii. Potential (and actual) loss of housing value in the areas where commercial sex services are being traded;

iv. Trafficking in human beings and under age commercial sex workers.

Another very relevant attribute of the commercial sex market has to do with its intrinsic informational problems. Asymmetric information exits between the commercial sex workers and clients because at first, only the supply side of the transaction, the commercial sex worker, knows the quality of the service. Negotiation for the transaction is subjectively done based on the assurances given to the client on the quality of the service. However, there is always contractual breach and opportunistic behaviour whenever clients discover huge discrepancies between the promised and post-transaction quality.

Although the contracting parties are commercial sex worker and client, others players that might be involved in the transaction are third party intermediaries whose presence drastically reduces both the direct and indirect costs of transaction. Direct cost refers to both the cost of bringing parties to the agreement and that of the transaction itself while indirect cost involves the inherent health and violence risks in the transaction. The intermediaries are usually exploiters who invest resources in, and expect profit from facilitating commercial sex service; they include traffickers, pimps and brothel owners. 
Inherent information asymmetry in the market is often corrected by intermediaries' concern for their reputation by offering quality signals to the potential clients before contracting. In this case, agencies act not as mere communication channels linking demand and supply, but also as information-reduction channels for the clients, as a means of product labelling, and as providers of contractual safeguards against breach, opportunistic behaviour and qualityreduction concerns (Moffatt and Peters 2004; Albert, Gomez and Franco 2007).

The health risk involving contracting and spreading of STDs, most especially HIV, which has been reported to have a positive relationship with commercial sex market growth without any effective vaccine or cure, is drastically changing the pricing structure in the market. This is done by promoting the use of condoms and other safe sex practices among sex workers (UNAIDS, 2002). Condom usage, not only directly prevents HIV infection, it also protects users from other sexually transmitted diseases which reduce the secondary increase in HIVrisk caused by STDs (Amoateng et al, 20I4 and Rao et al, 2003).

In addition to preferences and tastes, prices, income level, environmental, social, political, and religious factors drive commercial sex industry, Akinnawo (1995); Alobo and Ndifon (2014); AsowaOmoriodon (2000) and Ausbeth-Ajagun (2005) revealed the following as prominent factor in Nigeria:

$\checkmark$ Poverty and unemployment: Thesetwinevils that dehumanize their victim had plague Nigeria for long. They are the major reasons why commercial sex industry is still thriving because quite large number of commercial sex workers enters the industry to earn a living. Commercial sex in Nigeria is a serious social problem and its solution has been largely constrained by high poverty and unemployment levels.

$\checkmark$ Laziness: Commercial sex is seen as an easy business that generates fast money. Ladies who do not believe in hard-work philosophy view commercial sex work as a free business that can be done without stress and so devised numerous ways of seducing those perceived as wealthy members of the society who come across their ways. However, a function of the relative bargaining power of a client and a sex worker. The greater the sex worker's bargaining power, the closer the price differential is to the maximum a client is willing to pay. Secondly, when the client is worried about the risk of infection from unprotected sex, he may be charged more for using a condom than for unprotected sex. Also, when the sex worker prefers not to use a condom, the client is given a discount for not using a condom. In spite of an increase in sex worker's disutility from some (tertiary institution students) enter into the commercial sex market out of greediness.

$\checkmark$ Peer pressure: This often results to commercial sex work when sexually active individuals who hang-out or party together offer each other support for adventure and excitement. After receiving occasional payment for partying, they often start by engaging in pleasurable sex, which gradually becomes sex for monetary reward. The established individuals among them usually convinced newcomers to redefine the meaning of their sexual activity.

$\checkmark$ Trafficking and exploitation: This is associated with those who relocated from their places of origin based on promises of fantastic wellpaying jobs in other locations by some trusted individuals (sometimes relatives). They were to be later convinced or coerced into the commercial sex industry so as to pay their cost of relocation already borne by their supposed benefactors. Also, young women recruited by some corporate organisations as marketers and promoters are often intimidated to offer sex as precondition for patronage or in some cases as value-added services. Later, these women often found themselves offering sex to supplement their incomes.

One of the few economic theories on commercial sex was created by Edlund and Korn (2002), which held sex in marriage and with commercial sex worker as substitutes. It argued that only two options open to a woman are either to sell re-productive sex in marriage or on the market through commercialisation. It explains the relatively high wage of commercial sex workers as compensation for their foregone marriage opportunities. Selling of sexual services is not that different from selling of other services. A woman would, according to this model, only sell sex if she had few other opportunities on the labour or marriage market.

Gertler et al (2005) constructed a bargaining model of commercial sex with two predictions. Firstly, the price differential between protected and unprotected sex is a weighted average of the highest a client is willing to pay for not using a condom and the lowest a sex worker is willing to accept for not using condom. The weights are non-condom use, client's disutility from condom use remains greater than her disutility from non-condom use, and then a significant amount of unprotected commercial sex will continue to occur, although at higher price.

Hughes (2004) highlighted the components of demand as the exploiters, the traffickers and pimps, the states that fund deceptive messages and the culture that lies about the nature of commercial sex work. It further stated that these components need 
to be penalized to reduce the number of victims and pointed that if there were no men seeking to buy sexual acts, no women and children would be bought and sold; if there were no brothels waiting for victims, no victims would be recruited; if there were no states that profited from the sex trade, there would be no regulations that facilitated the flow of women from poor towns to wealthier sex industry centres; if there were no false messages about commercial sex work, no woman or girl would be deceived into thinking it is a glamorous or legitimate job.

Farley (2003) posited that the demand for commercial sex work creates its own supply. This is explained further that men want women that are constantly and sexually available and due to this, commercial sex work is said to be inevitable and as such, normal. Also, traffickers supply the demand for quality and variety of women and/or girls in commercial sex work. From its viewpoint, sex demanders, who purchase sex, are from all spheres of the world; doctors, judge, social workers, lecturers, student, young, old rich, poor etc. They claimed that the purchase of women in commercial sex work was to promote their health and satisfy their needs be it material, physical or sexual.

To Della Guista et al (2006), the propensity to gender violence, views on commercial sex work, views on sex workers, on relationships (in relation to commercial sex work), and preference for variety of sexual relationships are the factors that distinguish clients into two but radically opposite groups experimenters and regulars".iii. Value judgment variables also seem to play a role for demand: the more a client accepts gender violence and the more he is against sex work, the less he demands, but the more he believes that sex workers like their job, the more he demands. Also, modelled the market for commercial sex work and estimated the demand for commercial sex among arrested male clients, and find that the demand increases if the client has a full-time job, is non-white, or is not married (Della Guista et al 2008).

Della Giusta (2009) predicted a model that client will participate in the market for paid sex if their marginal willingness to pay for exceeds the price of paid sex, plus the marginal costs of a worsened reputation. The higher their reputation capacity (or ability to withstand stigma), the lower is the marginal cost from reputation effects of consuming commercial sex, and the more likely it is that commercial sex is consumed. Conversely, an individual will start to sell sex if the price of paid sex exceeds its opportunity cost, again in terms of reputation and alternative uses of one's time: the higher the price of paid sex, the more likely it is that an individual will supply commercial sex; the lower the availability of alternative income, the more likely it is that the individual will take part in the commercial sex industry; and the lower the effect of stigma on sex workers, the more likely it is that commercial sex will be sold. Hence, the equilibrium amount of commercial sex sold and bought in the market is a function of the exogenous parameters: reputation capacities of sex workers and clients, and other sources of income for sex workers.

Albert et al (2007) divided the commercial sex market into four different segments (escorts and call girls, brothels, house service, and street service) and argue that a single legal response to these four segments is not warranted from a social welfare point of view since the different segments differ in price, quality, asymmetric information, and negative externalities. Moffat and Peters (2004), Gertler et al (2005), and Rao et al (2003) all looked at the pricing of sex in general and the pricing and use of condoms in particular. They viewed the conservatives and those who support gender equality as more negatively prone toward commercial sex work in general. Also, those who hold anti-immigration views believe it is more morally acceptable to buy sex (Muindia et al 2014).

Similar to the submarkets identified by Albert et al (2007), Table I presents five sub-markets for commercial sex work in Nigeria. Although each of these submarkets differs in price and quality, they all share some common externalities. Furthermore, among these submarkets, the escort/out-call submarket is characterized by both high price and quality. In contrast, the street submarket is characterised by the lowest price and quality. Also, the role of intermediaries in the exchange of commercial sex services between seller and buyer of commercial sex is prominent in the escort, brothel and massage parlour submarkets while in the street and house submarkets intermediaries play no role. 
Table I: Commercial sex sub-markets and characteristics

\begin{tabular}{|c|c|c|c|c|c|}
\hline $\mathbf{S} / \mathbf{N}$ & Sub-market & Price & Quality & Intermediaries & Externalities \\
\hline I & $\begin{array}{l}\text { Escort / Out-Call } \\
\text { escort agencies maintain a } \\
\text { data base of employees } \\
\text { (commercial sex workers) of } \\
\text { different types. A luxury, high- } \\
\text { standard sub-market } \\
\text { dominated by young, pretty, } \\
\text { well-educated commercial sex } \\
\text { workers }\end{array}$ & very high & very high & $\begin{array}{l}\text { predominantly } \\
\text { available }\end{array}$ & $\begin{array}{l}\text { violence risks }{ }^{a} \\
\text { health risks }\end{array}$ \\
\hline 2 & $\begin{array}{l}\text { Brothels } \\
\text { bars, clubs, massage parlours } \\
\text { and other places where sex } \\
\text { worker is on public display }\end{array}$ & $\begin{array}{l}\text { Price discrimination due } \\
\text { to both the scale of } \\
\text { operation, (small, } \\
\text { modest road motel and } \\
\text { luxurious brothel) } \\
\text { quality of the service as } \\
\text { well as the available } \\
\text { time slot. }\end{array}$ & high & $\begin{array}{l}\text { predominantly } \\
\text { available }\end{array}$ & $\begin{array}{l}\text { violence risks; } \\
\text { health risks; } \\
\text { public disorder } \text {; } \\
\text { community } \\
\text { hazards }{ }^{d} ;\end{array}$ \\
\hline
\end{tabular}

\begin{tabular}{|c|c|c|c|c|c|}
\hline 3 & $\begin{array}{l}\text { House } \\
\text { sexual services provided at the } \\
\text { commercial sex workers' } \\
\text { homes. Advent of Information } \\
\text { and communication } \\
\text { technology (ICT) devices } \\
\text { make this popular }\end{array}$ & $\begin{array}{l}\text { price variation due to } \\
\text { the mode of operation } \\
\text { (part/full timer) }\end{array}$ & ambiguous & $\begin{array}{c}\text { Not usually } \\
\text { available }\end{array}$ & $\begin{array}{l}\text { violence risks; } \\
\text { health risks }\end{array}$ \\
\hline 4 & $\begin{array}{l}\text { Street } \\
\text { usually dressed in skimpy and } \\
\text { suggestive clothing and waits } \\
\text { or walks alongside a street } \\
\text { where clients are attracted in } \\
\text { the street transacting under } \\
\text { harshest condition in location } \\
\text { like inside cars, open spaces } \\
\text { or dark hide-out, etc. }\end{array}$ & low & low & Not available & $\begin{array}{l}\text { violence risks; } \\
\text { health risks; } \\
\text { public disorder } \\
\text { community } \\
\text { hazards; } \\
\text { opportunity } \\
\text { exploitation }\end{array}$ \\
\hline 5 & $\begin{array}{l}\text { Massage Parlour } \\
\text { providing massage while } \\
\text { sexual activities are provided } \\
\text { as value-added services. }\end{array}$ & high & High & Often available & $\begin{array}{l}\text { violence risks; } \\
\text { health risks }\end{array}$ \\
\hline
\end{tabular}

Source: Authors' compilation from survey of commercial sex literature

a. violence risks include murder, trafficking, assault, rape and battery.

b. health risks are contracting and spreading of STDs.

c. public disorder in the form of dirty streets, noise or scandal.

d. community hazards majorly involves reduction of the price of housing in the community

Since a client can be seen to be addicted to commercial sex consumption, this study has the theory of rational addiction of Becker and Murphy (1988) as the theoretical underpinning. Majorly, the theory assumes that an increase in past consumption stimulates the rise in current consumption, this action is assumed to involve tolerance and reinforcement. Reinforcement means that an increase in past commercial sex work increases the craving for present demand while tolerance means that the satisfaction from a given amount of commercial sex work is lower when past demand is greater. However, a rational client definitely considers the inherent risk in commercial sex work, hence; reinforcement requires that an increase in past commercial sex work stimulates the marginal utility of present demand by more than the present value is reduced through the marginal damage from future commercial sex work (Bask and Melkersson 2000).

Practically, the existence of the market clearing condition is doubtful in the commercial sex market due to some imperfections and failures that are likely to pervade the markets. Also, in reality, there is often no direct and observable transaction involving the buying and the selling of commercial sex due to the market inherent secrecy (Della Guista 2009). This implies the dearth of data on the price of commercial 
sex, without which the market equilibrium cannot be really determined.

However, as in other implicit markets, commercial sex workers are compensated on the basis of a set of different characteristics - physical attributes (age, complexion, facial outlook), level of education, the type and quality of services being provided. While rates are to some extent determined by negotiation, the market is competitive in nature and price is determined given the above mentioned attributes vis-à-vis the level of risk both party to the transaction is willing to take as manifested in the usage or otherwise of condom.

Following the above arguments, we assume a representative client with the instantaneous utility function:

$$
U[t]=U(b[t], H[t], y[t] \quad-\quad \quad \text { । }
$$

where $b[t]$ is the amount commercial sex worker demanded, $H[t]$ is a habit stock variable which measures the degree of addiction and $y[t]$ is a composite of other goods being demanded. Here, the habit stock was simply a stock of condom usage.

Since clients derive satisfaction from commercial sex, the derived marginal utility is assumed to be positive at a decreasing rate:

$$
U_{b}>0 \text { and } U_{b b}<0
$$

So also is the utility of the composite good:

$$
U_{y}>0 \text { and } U_{y y}<0-\quad-\quad 3
$$

Habit stock negatively affects utility through its numerous (health, violence, community and other) risks and this is done at an increasing rate:

$$
U_{H}<0 \text { and } U_{H H}<0 \quad-\quad 4
$$

However, commercial sex work has no effect on the marginal utility derived from consuming composite good, and vice versa:

$$
\begin{aligned}
& U_{b y}=U_{H y}=0 \\
& \text { The instantaneous utility function can be }
\end{aligned}
$$
approximated by:

$$
\begin{gathered}
U(.)=\alpha_{2} b[t]+\alpha_{3} H[t]+\alpha_{4} y[t]+\frac{1}{2} U_{b b} b^{2}[t] \\
+\frac{1}{2} U_{H H} H^{2}[t]+ \\
\frac{1}{2} U_{y y} y^{2}[t]+U_{b H} b[t] H[t]-
\end{gathered}
$$

where the $\alpha_{j}$ are positive parameters, and the $u_{i j} s$ are parameters with the same sign as the respective derivatives.

To derive the demand equation for a commercial sex worker, the representative client's problem is to choose $\{b[t]\}^{\infty}$ and $\{y[t]\}^{\infty}$ to maximize the discounted stream of utilities:

$$
\max _{b[t], y[t]} \sum_{t=1}^{\infty}(1+\sigma)^{-t} U(b[t], H[t], y[t])-7
$$

where $\sigma>0$ is the constant rate of time preference. The applicable budget constraint is

$$
\sum_{t=1}^{\infty}(1+r)^{-t}\left(p_{b}[t] b[t]+y[t]=W-8\right.
$$

where $r>0$ is the constant interest rate, $p_{b}[t]$ is the money price of commercial sex and $\mathrm{W}$ is the present value of wealth. Under a perfect market assumption, the rate of time and preference is equal to the interest rate, $\sigma=r$.

Substituting equation (8) into (7) give the maximization problem formulation:

$\max _{b[t], y[t]} \sum_{t=1}^{\infty}(1+r)^{-t}\left(U()-.\varphi\left(p_{b}[t] b[t]+y[t]\right)\right)$
-9

Deriving the first order condition with respect to $b[t]$ and solve for $b[t]$ led to the following demand equation for commercial sex market

$$
\begin{gathered}
b[t]=\beta_{0}+(1+r) \beta_{1} b[t-1]+\beta_{2} b[t+1]+ \\
\beta_{3} p_{b}[t] \quad-\quad-\quad 10 \\
\text { where } \beta_{0}>0, \beta_{1}>0, \beta_{2}<0 \text { and } \beta_{3}<0
\end{gathered}
$$

\section{Data and method}

\section{Model Specification}

Given the non-availability of data on the past and future demand for commercial sex work, our empirical model is limited to the current demand and hence, following Della Guista (2009), we estimated the following empirical demand model for the clients:

$$
\boldsymbol{y}=\beta_{0}+\beta_{1} \mathbf{x}_{i}+\beta_{2} \mathbf{w}_{i}+\varepsilon_{i}-\quad \text { II }
$$

where

$y$ is the frequency of the times clients have had sex with a commercial sex worker per week

$\mathbf{x}_{i}$ is a vector of individual regressors that include clients' characteristics such as marital status, age, education, income and employment status;

$\mathbf{w}_{i}$ is a vector of other market characteristics that include price of the service, price of other product, places of patronage and types of service being demanded;

$\varepsilon_{i} \quad$ is the error term; and

$\beta_{0}, \beta_{1}$ and $\beta_{2}$ are the parameters to be estimated.

\section{Description of Variables}

The dependent variable of our analysis is the number of times the client patronises a commercial sex worker per week, while the explanatory variables include price, price of other product, income and tastes and preferences as suggested by the theory. Specifically in our analysis, occupation, age and income (proxied by expenditure) reveal the characteristics of the clients; price of other product is measured by availability of a committed sexual partner (who may be a spouse or a friend); location of the commercial sex worker, time of visit and the type of the services being solicited for measure tastes and preferences. Notably, price of commercial sex 
(amount paid for the transaction) is measured in relation to condom usage which is always a subject of bargain either directly between the client and the commercial sex workers or through intermediaries, hence, the client who requires the condoms usage signals that he is more risk averse in his transactions. Table 2 provides the detailed description of the variable.

Table 2 Variables and their definitions

\begin{tabular}{ccc}
\hline Variable & Description & A-priori \\
\hline \multicolumn{1}{c}{ Dependent } \\
\hline TimPaWk & Number of times the client patronises a commercial sex worker per week & \\
\hline
\end{tabular}

\section{Independent}

\begin{tabular}{|c|c|c|}
\hline Agel & $=1$ if $20-29$ years old & + \\
\hline Age2 & $=1$ if $30-39$ years old & + \\
\hline Age3 & $=1$ if $40-49$ years old & \pm \\
\hline Age4 & $=1$ if 50 and above years old & - \\
\hline Marl & $=\mathrm{I}$ if single & + \\
\hline Mar2 & $=\mathrm{I}$ if married & - \\
\hline Mar3 & $=\mathrm{I}$ if others marital status & \pm \\
\hline Spouse_Live & $=\mathrm{I}$ if married and living together with the spouse & - \\
\hline Single_Relate & $=\mathrm{I}$ if single and having stable relationship & - \\
\hline Dependant & Number of dependants & - \\
\hline First_Sex_age & Age had first sexual experience & + \\
\hline Paid_Sex_age & Age first paid for sex & + \\
\hline Workl & $=\mathrm{I}$ if in formal employment & \pm \\
\hline Work2 & $=\mathrm{I}$ if unemployed & + \\
\hline Work3 & $=1$ if self employed & \pm \\
\hline Work4 & $=\mathrm{I}$ if undergraduate student & \pm \\
\hline Work5 & $=\mathrm{I}$ if postgraduate student & \pm \\
\hline Spending I & $=\mathrm{I}$ if spend below $\triangleq 10,000$ & \pm \\
\hline Spending2 & 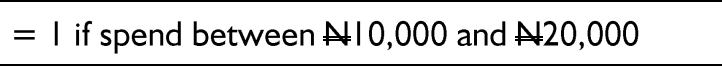 & \pm \\
\hline Spending3 & $=1$ if spend between $₫ 20,000$ and $₫ 30,000$ & \pm \\
\hline Spending4 & 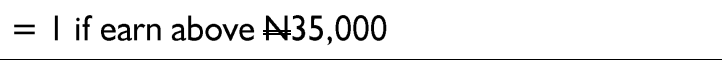 & \pm \\
\hline RegulaCust & $=\mathrm{I}$ if client demand for sex regularly & + \\
\hline Place I & $=\mathrm{I}$ if patronises streets & + \\
\hline Place2 & $=\mathrm{I}$ if patronises brothels & + \\
\hline Place3 & $=1$ if patronises clubs/bars & + \\
\hline Place4 & $=1$ if patronises house & + \\
\hline Timel & $=1$ if demand in weekdays & + \\
\hline Time2 & $=\mathrm{I}$ if demand in weekend & + \\
\hline Servicel & $=\mathrm{I}$ if demand for short time service & + \\
\hline Service2 & $=\mathrm{I}$ if demand for per night service & + \\
\hline
\end{tabular}




\begin{tabular}{ll}
\hline Service3 & I I f demand for others service \\
\hline SSTCon & Amount paid for street short time with condom \\
\hline SSTWCon & Amount paid for street short time without condom \\
\hline SPNCon & Amount paid for street per night with condom \\
\hline CSTCon & Amount paid for clubs/bar short time with condom \\
\hline CSTWCon & Amount paid for clubs/bar short time without condom \\
\hline CPNCon & Amount paid for clubs/bar per night with condom \\
\hline CPNWCon & Amount paid for clubs/bar per night without condom \\
\hline BSTCon & Amount paid for brothel short time with condom \\
\hline BSTWCon & Amount paid for brothel short time without condom \\
\hline BPNCon & Amount paid for brothel per night with condom \\
\hline ISCon & Amount paid to intermediaries for short time with condom \\
\hline ISWCon & Amount paid to intermediaries for short time without condom \\
\hline IPNCon & Amount paid to intermediaries for per night with condom \\
\hline IPNWCon & Amount paid to intermediaries for per night without condom \\
\hline
\end{tabular}

\section{Sources of data}

There is no official data available on the nature and pattern of commercial sex services in Nigeria, hence, the need to conduct a survey. This study was carried out in Ibadan metropolis in south west of Nigeria. Ibadan, the capital city of Oyo State, has II Local Government Areas (LGAs) distributed as five city and six less-city LGAs categorisation. It is the third largest metropolitan area in Nigeria, after Lagos and Kano, with a population of $2,550,593$ covering 3,080 square kilometres according to 2006 census.

All clients that demand for commercial sex services irrespective of locations in lbadan are the population for this study. However, since it is not a legalised service in Nigeria, it was not possible to locate all expected agents (especially corporate or individual intermediaries) in the market, nonetheless, the study employed multi-stage sampling procedure. At the first stage, Ibadan North Local Government Area was purposively selected for the study because it has the largest resident population in the city (308, I 19 - 2006 census) as well as a good number of brothels. For the second stage, seven (7) brothels with noticeable presence of commercial sex workers and three (3) prominent areas where street commercial sex work exists were purposively selected. To give every client an equal chance of selection in the survey at the final stage, eighteen (18) clients were randomly and discretely selected through the help of pimps, brothel workers or commercial sex worker. Hence, one hundred and eighty (180) clients were selected altogether and they formed the sample size for the study.

In order to collect valid and reliable data for the study, questionnaire was developed and used as instrument to gather data from the field. The questionnaire is structured into two sections: Section A gathered information on demographics (bio-data) of the clients while Section B collected information on the type of services being demanded, preferred time and location as well as the amount paid for different transactions. The different services offered by the commercial sex workers are short time, per night and others (lap dance, anal, fellatio and host of others). All these are held in different locations like street, clubs/bar, brothel, house and other places mutually agreed by the parties. The study covered the four (street, clubs/bar, brothel, intermediaries house/escort) identified sub-market ${ }^{\mathrm{iv}}$ and amount paid for the two major mode of transactions (short time and per night). Also, since the price charged was discovered to be a function of condom usage, it was segregated along the risk averse (with condom) and risk loving (without condom) clients across all the four sub-markets. The monetary value used was Nigeria naira.

For validity of our instrument (measuring what is intended to measure), content (or face) validity was used; we gave the questionnaire to experts (in population field) for perusal and their suggestions were considered in re-shaping the instrument. This enabled us to determine the extent to which the contents indeed matched the study objectives. For 
reliability (get the same answer each time we are measuring the same issue), stability (test-retest) was adopted; to test this, we administered the same instrument twice, separated by three-week duration and calculated the correlation between the outcomes of the instrument at first and second times. We achieved a correlation coefficient 0.82 and affirmed that we had very good reliability.

However, upon administration of the questionnaire on the clients (who were encouraged to fill the questionnaire by the pimps, brothel workers or commercial sex worker at the point of patronage); one hundred and sixty-eight (I68) questionnaires were found useful and were analysed appropriately. The empirical model was estimated using Ordinary Least Squares (OLS) technique through Stata II software. Table 3 present the relevant descriptive statistics of the respondents.

Table 3 Descriptive statistics

\begin{tabular}{|c|c|c|c|}
\hline Variable & Observation & Mean & Standard Deviation \\
\hline \multicolumn{4}{|c|}{ Dependent } \\
\hline TimPaWk & 168 & 1.286 & 0.667 \\
\hline \multicolumn{4}{|c|}{ Independent } \\
\hline Agel & 168 & 0.262 & 0.441 \\
\hline Age2 & 168 & 0.524 & 0.501 \\
\hline Age3 & 168 & 0.143 & 0.351 \\
\hline Age4 & 168 & 0.071 & 0.258 \\
\hline Marl & 168 & 0.333 & 0.473 \\
\hline Mar2 & 168 & 0.476 & 0.501 \\
\hline Mar3 & 168 & 0.190 & 0.394 \\
\hline Spouse_Live & 112 & 0.321 & 0.469 \\
\hline Single_Relate & 56 & 0.643 & 0.483 \\
\hline Dependant & 168 & 1.762 & 2.004 \\
\hline First_Sex_age & 168 & 18.786 & 2.658 \\
\hline Paid_Sex_age & 168 & 21.357 & 3.411 \\
\hline Workl & 168 & 0.214 & 0.412 \\
\hline Work2 & 168 & 0.119 & 0.325 \\
\hline Work3 & 168 & 0.143 & 0.351 \\
\hline Work4 & 168 & 0.189 & 0.180 \\
\hline Work5 & 168 & 0.335 & 0.341 \\
\hline Spending I & 168 & 0.571 & 0.496 \\
\hline Spending2 & 168 & 0.262 & 0.441 \\
\hline Spending3 & 168 & 0.095 & 0.294 \\
\hline Spending4 & 168 & 0.071 & 0.258 \\
\hline RegulaCust & 168 & 1.714 & 0.453 \\
\hline TimePWk & 168 & 1.286 & 0.667 \\
\hline Place I & 168 & 0.119 & 0.325 \\
\hline Place2 & 168 & 0.143 & 0.351 \\
\hline
\end{tabular}




\begin{tabular}{llcc}
\hline Place3 & 168 & 0.500 & 0.501 \\
\hline Place4 & 168 & 0.238 & 0.427 \\
\hline Timel & 168 & 0.214 & 0.412 \\
\hline Time2 & 168 & 0.786 & 0.412 \\
\hline Servicel & 168 & 0.667 & 0.473 \\
\hline Service2 & 168 & 0.167 & 0.374 \\
\hline Service3 & 168 & 0.167 & 0.374 \\
\hline SSTCon & 168 & 517.86 & 188.22 \\
\hline SSTWCon & 168 & 1071.4 & 320.39 \\
\hline SPNCon & 168 & 550 & 240.01 \\
\hline CSTCon & 168 & 1004.8 & 296.04 \\
\hline CSTWCon & 168 & 2023.8 & 152.91 \\
\hline CPNCon & 168 & 2907.1 & 399.04 \\
\hline CPNWCon & 168 & 3464.3 & 229.37 \\
\hline BSTCon & 168 & 528.57 & 176.85 \\
\hline BSTWCon & 168 & 1500 & 0 \\
\hline BPNCon & 168 & 1023.8 & 152.91 \\
\hline ISCon & 168 & 271.43 & 302.71 \\
\hline ISWCon & 168 & 3000 & 0 \\
\hline IPNCon & 168 & 4264.3 & 866.91 \\
\hline IPNWCon & 168 & 5000 & 0 \\
\hline
\end{tabular}

Information emanating from Table 3 , which presents the relevant descriptive statistics of the respondents, shows that the clients demanded for commercial sex services more than once (1.29) per week on the average. The clients between 30 and 39 years of age patronises commercial sex worker more $(52.3 \%)$ than other age groups on the average and the majority of them are married $(47.6 \%)$. Though, they averagely became sexually active around 18 years of age, it was until they reach 21 years that they started paying for sex. However, they are predominantly post graduate students and followed by those in formal employment. Curiously, $57.1 \%$ of them claim to earn below NI0,000 (about USD60) monthly. Clubs/bar happened to the place with highest average patronage $(50.0 \%)$ which were mostly done on weekends $(78.6 \%)$, and short time service happened to be the most demanded transaction $(66.7 \%)$.

However, per night transactions without condom both on the streets (SPNWCon) and in the brothels (BPNWCon) were not demanded by the responding clients, hence, they were deleted from the analysis.

Average pricing system varies by the different submarkets and type of services rendered. The pricingstructure confirmed the risk nature of the clients as the average amounts charged without condom usage were higher than with condom usage in all the sub-markets. For the services rendered, short times were generally lower than per night services. On the sub-markets, street charged lowest, followed by the brothel and club/bars while those who engage the services of the intermediaries had highest charges.

\section{Results and discussion}

Table 4 presents the econometric results of the demand for commercial sex services in Ibadan, Nigeria. The reference categories for the categorical variables are the category with highest observations among the relevant categories. In this regard, they are: Age 30 - 39 (age2), Married (mar2), Postgraduate Student (work4), Below N10,000 (spendingI), Clubs/Bars (Place3), Weekends (Time2) and Short Time (Servicel). Natural logarithm of all the amount charged were used while short time transactions without condom in the brothel (BSTWCon), short time transactions without condom through intermediaries (ISWCon), per night transaction with condom in brothel (BPNCon) as well as per night without condom through 
intermediaries (IPNWCon) were collinear and were subsequently removed from the analysis.

The results indicate the demand side of the female heterosexual commercial sex market in Nigeria is indeed conditioned by some individual and household characteristics, risk disposition as well as the opportunities to conceal such demand by the clients.
Specifically, the result shows that the demand is inversely related to age and this is evident among age group 20 - 29 who demanded more and 40 and above that demanded less than the reference group.

Table 4 Estimation results

\begin{tabular}{|c|c|c|c|c|}
\hline TimPaWk & Coef. & $\mathrm{t}$ & $P>|t|$ & Sig \\
\hline Age I & 0.266 & 2.400 & 0.018 & **⿻丷木 \\
\hline Age3 & -0.162 & -1.170 & 0.243 & \\
\hline Age4 & -0.580 & -2.470 & 0.015 & *** \\
\hline Marl & 0.361 & 2.810 & 0.006 & *** \\
\hline Mar3 & -1.010 & -6.560 & 0.000 & **** \\
\hline Spouse_Live & 0.180 & 1.810 & 0.073 & $*$ \\
\hline Single_Relate & 0.047 & 0.520 & 0.606 & \\
\hline Dependant & 0.554 & 14.350 & 0.000 & **** \\
\hline First_Sex_Age & -0.449 & -14.530 & 0.000 & **** \\
\hline Paid_Sex_Age & 0.059 & 3.630 & 0.000 & **** \\
\hline WorkI & -1.472 & -8.780 & 0.000 & **** \\
\hline Work2 & 0.734 & 5.250 & 0.000 & **** \\
\hline Work3 & -0.923 & -6.530 & 0.000 & **** \\
\hline Work5 & -0.373 & -2.800 & 0.006 & *** \\
\hline Spending2 & 0.743 & 9.830 & 0.000 & **** \\
\hline Spending3 & 0.359 & 2.700 & 0.008 & *** \\
\hline Spending4 & 1.958 & 7.780 & 0.000 & **** \\
\hline Place I & 0.553 & 4.760 & 0.000 & ***** \\
\hline Place2 & -1.010 & -8.590 & 0.000 & **** \\
\hline Place4 & 0.457 & 3.080 & 0.003 & *** \\
\hline Timel & 0.228 & 2.310 & 0.023 & *** \\
\hline Service2 & 2.053 & 12.540 & 0.000 & **** \\
\hline Service3 & 1.090 & 7.110 & 0.000 & **** \\
\hline Regular I & -0.162 & -1.970 & 0.051 & *** \\
\hline $\ln ($ SSTCon) & -0.682 & -5.290 & 0.000 & **** \\
\hline In(SSTWCon) & -0.343 & -1.050 & 0.294 & \\
\hline $\ln ($ SPNCon) & -2.664 & -5.740 & 0.000 & $* * *$ \\
\hline $\ln ($ CSTCon) & 1.976 & 8.500 & 0.000 & $* * *$ \\
\hline $\ln ($ CSTWCon) & 2.330 & 2.040 & 0.043 & *** \\
\hline $\ln ($ CPNCon) & 1.012 & 3.930 & 0.000 & **** \\
\hline $\ln$ (CPNWCon) & 0.953 & 1.240 & 0.215 & \\
\hline In(BSTCon) & 0.035 & 0.140 & 0.887 & \\
\hline $\ln$ (ISCon) & 1.005 & 8.250 & 0.000 & **** \\
\hline In(IPNCon) & -1.901 & -6.860 & 0.000 & **** \\
\hline cons & -6.659 & -0.550 & 0.586 & \\
\hline
\end{tabular}

*, ** and ${ }^{* * * *}$ significant at $p<0.1, p<0.05$ and $p<0.0$ I respectively.

Dependent variable: Client's Patronage per week

As expected concerning the marital status, the singles' demand is higher than married while the spouse co-living is positively and significantly related to the demand, so also the availability of the 
dependants in the household. All the professions covered in the study significantly determine the demand with only the unemployed demanding more than the postgraduate students, other groups demand for less. Also, the relationship between demand and income was positive and significant affirming commercial sex as a normal good among the clients (highest earners demand most).

On the sub-markets, the result reveals brothels was lightly patronised while streets and house were highly patronised when compared to clubs/bars this may be as a result of the perceived stigma expected to be suffered by the clients when the public is aware of the demand. Also, demand was found to be relatively higher during the weekdays compared to the weekends. Regarding the type of transaction in terms of the patronage per week, per night and other services are positive and statistically significant than the short time, this could be due to the perceived satisfaction expected to be derived from the varieties being offered under these kinds of services.

The price variables equally affirmed the risky nature of the commercial sex market. With the exception of short time service in clubs/bars, demands for services without condom in other submarkets are not significantly different from zero. This implies that the market is highly averse to the health and violence risks pervading the market. For the services with condom, short time and per night on street as well as per night through intermediaries were inversely related to patronage suggesting that offering these services are with reluctance possibly due to the apparent stigma expected to be suffered by the clients when the public is aware of the demand and the higher charges of intermediaries respectively.

Short time and per night in clubs/bars and short time through intermediaries are positively related. In the order of the pricing from highest to lowest influences, we have short time in clubs/bars, per night in clubs/bars, short time through intermediaries, short time on street, per night through intermediaries and per night on street respectively. The implication of this scenario is that the demand is increasing with short time service without condom at clubs/bar, short time and per night in clubs/bars with condom and short time through intermediaries with condom while it is decreasing with short time and per night with condom on street as well as per night with condom through intermediaries. Moreover, the nature of risk is more pronounced with clubs/bar clients being more risk loving and others more risk averse based on their respective significant condom usage.

\section{Conclusion and policy implications}

The results indicate a very strong, booming and robust female heterosexual commercial sex market in Ibadan Nigeria. The facts emanating from our findings show that the demand is highly responsive to income, marital status (price of other commodities), tastes and preferences as well as the price predominantly with respect to condom usage. Summarily, the clients are rational economic agents who respond to risk and situational opportunity in engaging the commercial sex workers. Our results appear to be consistent with Cameron and Collins (2003), Jakobsson and Kotsadam (2009), Della Giusta et al (2009) and host of other studies.

Furthermore, our evidence also confirms that the majority of the commercial sex workers transact due to economic gains being derived from men in the society, most especially, in the absence of other valid alternatives. This confirms that demand, with its multifaceted characteristics, is the actual driving force for supply in the commercial sex market.

Married couples should strive to live together as much as possible to minimise the spouse's tendency for commercial sex patronage while genuine effort should be exerted by Governments, NonGovernment Organisations (NGOs), Religious Organisations and Communities towards the reduction of the demand and focus on finding alternative solutions to relationship problems, sexuality and sexual identity through social reengineering.

Also, there should be institutionalised system of penalising the demand-side players, that is, the clients who purchase sexual acts and the intermediaries who profit from the trade, and the cultures that pretend about the nature of commercial sex work. This should, therefore, inform the regulatory design of the market, which is currently overwhelmingly concerned with supply-side considerations. Failure to understand the demand side of this phenomenon is more likely to generate ineffective policy outcomes.

Given that commercial sex work is illegal in the country, its attendant stigma and the coercive nature of the trade made it highly difficult to access a wider range of respondents. Also, due to the nature of the approach chosen for this research, the results may lack generalisation.

\section{References}

Adeshina, O. 2006. "Between Culture and Poverty:

The Queen Mother Phenomenon and Edo International Sex Trade", Journal of Culture and African Studies, 8.

Adriaenssens, S. 2010. "It's all Supply and Demand: Market Fatalism and Norm Construction by Prostitution Clients in the Netherlands and 
Belgium”.HUB Research Papers. Brussels, HUB University College, I - 2I.

Aggleton, P. (ed.) 1998. Men who sell sex. London: UCL Press.

Akinnawo, E.O. 1995. "Mental health implications of the commercial sex industry in Nigeria", Health Transition Review 5, I73-I77.

Albert, R., Gomez F. and Franco Y. 2007. "Regulating Prostitution: A Comparative Law and Economics Approach", Fundacion de Estudios de Economia Aplicada (FEDEA), DOCUMENTO DE TRABAJO 30.

Alobo E. and Ndifon R. 2014. "Addressing Prostitution Concerns in Nigeria: Issue, Problems and Prospects", European Scientific Journal 10, (14): 36-47.

Amoateng A., Kalule-Sabiti I. and Arkaah Y. 2014. "The Effect of Socio-Demographic Factors on Risky-Sexual Behaviours of Adolescents in the North West Province of South Africa", Etude de Population Africaine/African Population Studies 28, (I): 487-498.

Asowa-Omorodion, F.I. 2000. "Sexual and health behaviour of commercial sex workers in Benin City, Edo State, Nigeria", Health care for women international 21, (4): 335-345.

Ausbeth-Ajagun, A. 2005. "Prostitution" Youth and Gender Network. Available at www.youthgendernetwork.com. Accessed on 10 June 2013.

Babatola O. 201I. "Model variables of risk elements in sexual behaviour: a comparative analysis of Lagos-based traders", Etude de Population Africaine/African Population Studies 25, (I): 26-43.

Bask M. and Melkersson M. 2000. Rational Addiction and Smoking when there are Legal and Illegal Cigarettes, Department of Economics, Stockholm University, Sweden.

Becker G. and Murphy K. 1988. "Theory of Rational Addiction" Journal of Political Economy,96: 675700.

Cameron, S. and Collins A. 2003. "Estimates of a Model of Male Participation in the Market for Female Heterosexual Prostitution Services", European Journal of Law and Economics, 16 (3): 27I-288.

Cameron, S., Collins, A. and Neill, T. 1999. "Prostitution Services: An Exploratory Empirical Analysis", Applied Economics 31, (I2): I523-I529.

Cockayne, A. 200I. "Prostitution and Sexual Exploitation in the European Union" Undergraduate Research Paper produced for POL 3037 - The politics of policing Transnational Crime in Europe. Department of Politics, University of Exeter. Available at www.ex.ac.uk/ politics/poldata/undergrad/aac
Cook C., Loring S., Niemic T. and Reinherz K. 2014. "Macroeconomic Forces within the Market for Prostitution”, Comparative Advantage 2, (2): 8494.

Della Guista, M. 2009. "Who is watching? The Market for Prostitution Services", Journal of Population Economics 22, (2): 50I-5I6.

Della Guista, M., Di Tommaso, M. and Strøm, S. 2008. Sex Markets: A Denied Industry. London and New York: Routledge.

Della Guista, M., Di Tommaso, M., Shima, I. and Strøm, S. 2006. "What Money Buys: Clients of Street Sex Workers in the US", Memorandum Series No 10, Department of Economics, University of Oslo, Norway.

Edlund, L., and Korn, E. 2002. "A Theory of Prostitution", Journal of Political Economy, I I0, (I): $|8|-2 \mid 4$.

Farley, M. 2003. "Prostitution and the Invisibility of Harm", Women \& Therapy 26, (3/4): 247-280.

Fels, R. 197I. The Price of Sin. In H. Townsend (ed.), Price Theory: Selected Readings. Harmondsworth, UK, Penguin.

Gertler, P., Shah, M. and Bertozzi S. 2005. "Risky Business: The Market for Unprotected Commercial Sex", Journal of Political Economy II3, (3): 518-550.

Greenall, M. 2008. Sex Work and Economics. A Rapid Annotated Bibliography Conducted for the Paulo Longo Research Initiative, PLRI.

Hubbard, P. 1998. "Community Action and Displacement of Street Prostitution: Evidence from British Cities", Geoforum 29, (3): 269-286.

Hughes, D. 2004. Prostitution: Causes and Solutions. Spain. Santiago de Compostela, Galicia.

Jakobsson, N. and Kotsadam, A. 2009. "What explains attitudes towards prostitution?" Working Papers in Economics No. 349.

Levitt, S. and Venkatesh S. 2007. Analysis of Street-Level Prostitution, Mimeo.

Mansson, S. 2006. "Men's Demand for Prostitutes", Sexologies 15, 86 - 92.

Martilla, A. 2003.Consuming Sex - Finnish Male Clients and Russian and Baltic Prostitution. Paper Presented at the $5^{\text {th }}$ European Feminist Research Conference: Gender and Power in New Europe. Finland.

Moffatt, P. and Peters S. 2004. "Pricing Personal Services: An Empirical Study of Earnings in the UK Prostitution Industry", Scottish Journal of Political Economy5I, (5): 675 - 690.

Muindia K., Mudege N. Beguy D. and Mberu B. $20 \mid 4$. "Migration and sexual behaviour among youth in Nairobi's slum areas", Etude de Population Africaine/African Population Studies 28, (3): I2971309. 
Nussbaum, M. 1999. Sex and social justice. New York: Oxford University Press.

Ogunkan D., Omoruan A. and Fawole O. 2010. "Environmental and socio - economic dimensions of prostitution in Ogbomoso, Oyo State", Ife Research Publications in Geography 9, (I): 282 300

Philipson, T. and Posner, R. 1993. Private Choices and Public Health: The AIDS Epidemic in an Economic Perspective. Cambridge, Mass: Harvard Univ. Press.

Posner, R. 1992. Sex and Reason.Cambridge, Mass: Harvard Univ. Press

Rao, V., Gupta, I., Lokshin, M. and Jana, S. 2003. "Sex Workers and the Cost of Safe Sex: The Compensating Differential for Condom Use among Calcutta Sex Workers", Journal of Development Economics 7I, (2): 585-603.

Raymond, J. 2004."Prostitution on Demand: Legalizing the Buyers as Sexual Consumers", Violence against Women 10, (10): II56- II86.

Reynolds, H. 1986. The economics of prostitution. Illinois: CC Thomas.

Ryley, S. 1936. A history of prostitution form antiquity to present. Delhi: Shubhi Publications.

Taylor, J. 200I. "Dollars are a girl's best friend? Female tourists' sexual behaviour in the Caribbean", Sociology: Identity Politics in the Workplace 35, (3): 749-764.

UNAIDS, 2002. Report on the Global HIV/AIDS Epidemic. UNAIDS, Geneva.

West, D. 1992. Male Prostitution: Gay Sex Services in London. London: Duckworth.

\section{Notes}

Production, supply and consumption of legal commodities are free with restrictions placed on the illegal ones which trading is a punishable offense under law when caught.

ii Others include child labour, drugs, arms and ammunitions, smuggling, human trafficking, violence, robberies, rape and several others.

iii The first are experimenters, who see commercial sex as a complement to stable relationships, hold negative views of women and of sex workers. The second are the regulars, who hold more liberal views, find relationships a burden and for whom paid sex is a normal good whose demand increases with income. The experimenters demand for more sex and like to dominate while the regulars do the opposite. The experimenters are more risk loving and regulars more risk averse.

iv Massage parlours are relatively scarce in the study area 